ЂОРЂЕ ЂОРЂЕВИЋ

Универзитет у Нишу, Филозофски факултет, Ниш

DOI 10.5937/kultura1652026D

УДК 791.2:007.5

141.7:60

стручни рад



Сажетак: Филмска уметност је антиципирала многе трансхуманистичке идеје које су тек данас постале актуелни предмет разматрања. Седма уметност је указала на бројне етичке дилеме и контроверзе са којима се човечанство сусреће онда када се налази пред различитим изазовима трансхуманизма. У филмским делима Холивуда то је најадекватније приказано на примеру киборга. Стварајући дистопијска дела посвећена киборзима (филмови, телевизијске серије, графичке новеле) и профитирајући на юима, медијска индустрија користи мешавину радозналости и страха која постоји код савремених људи који су суочени са убрзаним развојем технологије која мењ ю юиово сочијално окружене. У самој социјалној реалности захваљујући развоју технологије, киборг је од медијског феномена временом постао део садашњости и непосредне будућности. Живимо у времену у којем пропитујемо досадашње дефинииије и идентитет човека под светлом новог хибридног идентитета киборга као директног споја човека и машине.

Кључне речи: киборг, дистопије, трансхуманизам, седма уметност, филм, масовни медији. 


\section{$Y_{60} \partial^{l}$}

Период након Другог светског рата обележен је почетком дуготрајног хладног рата и непрекидним тензијама између великих сила. Страх од нуклеарног сукоба и могућности нестанка целог човечанства изазивао је непрекидни осећај нелагодности и анксиозности. Обични грађани али и интелектуалци разумевали су сву комплексност тог историјског периода. Либералне мислиоце је с једне стране бринула опасност успостављања неког тоталитарног поретка на светском нивоу, док је с друге стране постојала зебња да би након планетарног сукоба нуклеарних сила преживели људски род био враћен на ниво првобитне људске заједнице. Отуда у периоду након Другог светског рата настаје велики број књижевних и филмских дистопија у којима су изражени ови страхови.

Чини се да је Урлих Бек (Ulrich Beck) био у праву када је рекао да живимо у ризичном друштву. ${ }^{2}$ Константна анксиозност и страх од природних и вештачки изазваних катастрофа, еколошких акцидената и могућих терористичких напада продужила се и након пада Берлинског зида 1989. године и очекиваног краја историје. ${ }^{3}$ Не само да су се ризици повећавали, већ је и ниво свести о њима захваљујући масовним медијима и образовном систему растао, тако да је осећај нелагодности постао хроничан. Нова нелагодност у култури је претходних деценија бујала упоредо са развитком технологије и различитим могућностима њене злоупотребе. Просвећени мислиоци су јасно сагледавали и њен деструктивни потенцијал и разумевали су да она и поред свих предности представља опасан мач са две оштрице.

Киборг (енг. cyborg - cybernatic organism) о којем је писала Дона Харавеј (Donna Haraway) представљао је метафору и само мрачну слику неке, ипак нешто даље будућности, тако да нико није очекивао да ће се то питање ускоро наметнути као део агенде свакодневних разматрања. Приказ киборга у књижевности, на филму и у графичким новелама јесте покушај сагледавања сутрашњице, али и проактивно настојање

1 Рад је настао као резултат истраживања холивудског филма за потребе одбрањене (и необјављене) докторске тезе из области социологије културе (25. 09. 2015. године, Филозофски факултет, Универзитет у Нишу) под називом: Đorđević, Đ. Р. (2015) Film i tržište: vidovi komercijalizacije savremenog holivudskog filma, doktorska disertacija (unpublished), Filozofski fakultet, Univerzitet u Nišu, Niš.

2 Bek, U. (2001) Rizično društvo: u susret novoj moderni, Beograd: „Filip Višnjić".

3 Fukujama, F. (2002) Kraj istorije i poslednji čovek, Podgorica: CID; Banja Luka: Romanov. 
да се унапред добију одговори на то како ће његова појава утицати на људски род. Шта ће се догодити са бићем знаним као homo sapiens оног тренутка када (и ако) киборгизација људског рода буде омасовљена. Са развојем технологије она лако може бити претворена у неку нову врсту раширене моде, баш као што су данас тетоваже, пирсинзи и пластична хирургија већ свакидашња ствар.

Како нас подсећају медицински радници, савремен спој човека и машине (специјалних електронских протеза и помагала) код појединих врста телесних оштећења и болести, учинио је да једна врста киборга постане наш савременик. ${ }^{4}$ За сада је киборгизација људи ограничена само на оне којима та технологија спасава или олакшава живот. Истовремено, некада је то био случај и са класичном хирургијом која је била ствар нужде, док данас естетска хирургија истовремено представља питање моде (укључујући и избор жељеног модела) и личне одлуке, некада и хира.

Сасвим је извесно да захваљујући идеалу трансхуманизма, о којем ће бити речи у раду, данашње човечанство клизи ка будућности у којој ће питање киборгизације човека постати ствар властите одлуке чак и код физички потпуно здравих људи. Проблем је у томе што ће та одлука некада заправо бити изнуђена и представљати резултат притисака неке нове трансхуманистички обојене културе, моде, а у неким случајевима можда чак и појединих тоталитарних режима.

\section{Филмске дистопије}

Један од задатака науке је и да предвиђа како ће друштво изгледати у блиској будућности. Тај посао није нимало лак и обично је праћен многим погрешкама, што је сасвим разумљиво. На основу већ постојећих тенденција научниксоциолог покушава да (макар донекле) предвиди сутрашњицу. Социолог као истраживач и аналитичар успешно сагледава разлику између онога што нека социјална појава јесте у садашњем тренутку и онога што она потенцијално може да постане. По томе је он донекле сличан уметнику, тако да се њихове социјалне улоге по овом питању донекле укрштају, али и међусобно корисно допуњују. Јер „уметност није управљена само према актуелним проблемима и стању hic et nunc. Визије праве уметности иду иза самих ствари, изван домашаја неуметничких видика. Уметност не говори само о актуелном човеку, већ и о потенцијалном човеку, не само о човеку какав јесте, већ и о томе какав би могао и

4 Јовићевић, Д. (28. јуна 2012) Концепт симбиозе, Нин, стр. 56. 
какав би требало да буде у потоњим хуманијим социјалним условима". 5

Да уметност и друштвене науке могу бити међусобно инспиративне области рада и стварања, можда се понајбоље види на примеру соиијалних дистопија. Социјалне дистопије су увек биле на граници између социологије и књижевности. Управо је квалитет дела као што су 1984 Џорџа Орвела (George Orwell), Врли нови свет Олдоса Хакслија (Aldous Huxley) и Фаренхајт 451 Реја Бредберија (Ray Bradbury), учинио да она често буду цитирана и у радовима многих релевантних социолога. Без обзира што социјалне дистопије нису социолошко штиво у ужем смислу, њихов прелазни карактер чини да могу бити назване социолошким романом - баш као што постоје и психолошки роман и историографски роман. Готово све утопије и дистопије исписане су у романескној форми, али она је само „средство да се искаже идеја, по правилу социјалнотеоријска". ${ }^{6}$

Дистопија представља негативну утопију, њену супротност. Као антиутопија, она не приказује неко идеално друштво као што то чине класичне утопије, већ слика негативно друштво будућности, засновано на свеопштем тоталитаризму и контроли грађана. Најчешће је то друштво и технолошки знатно напредније од времена када сам аутор ствара свој дистопијски роман, али та технологија примарно се употребљава као средство апсолутне репресивне контроле људи. Данас такође постоји велики број филмских дистоnија које су ништа мање познате него њихови књижевни претходници. Код неких од њих постоји и незнатна измена у односу на класичну дистопијску књижевност. У појединим холивудским филмовима обично је реч о дистопијама које су настале након неког колапса цивилизације, било да је он изазван III светским ратом, константним еколошким загађењем, социјалним немирима, економском кризом или пак неком случајном нуклеарном или хемијском катастрофом. Друштво замишљене будућности након таквог колапса цивилизације представља својеврсну мешавину наново успостављеног племенског уређења и преосталог оскудног знања о коришћењу понеког сачуваног технолошког уређаја из прошлости.

Не мора сваки постапокалиптични филм истовремено бити и филмска дистопија, али она филмска дела која ту фиктивну

5 Božilović, N. (2008) Umetnost, kreacija, komunikacija, Niš: Filozofski fakultet, str. 10 .

6 Милосављевић, Љ. (2008) Под/стицање слободе: нововековна мисао о друштву, Ниш: Филозофски факултет, стр. 337. 
заједницу будућности приказују као тоталитарно друштво свакако то јесу. Због актуелности ове теме многе филмске дистопије током каснијих година добијају своју римејк (remake) или рибут (reboot) верзију. У познате америчке филмске дистопије спадају: Еквилибријум/Equilibrium (2002, Kurt Wimmer), Игре глади/The Hunger Games (2012, Gary Ross), Krbuza cnaca/The Book of Eli (2010, Albert Hughes; Allen Hughes), Матрикс/The Matrix (1999, Laurence/Lana Wachowski; Andrew Paul Wachowski), Гатака/Gattaca (1997, Andrew Niccol), Робокаn/RoboCор (1987, Paul Verhoeven), Сувишни извештаj/Minority Report (2002, Steven Spielberg), Тркач/The Running Man (1987, Paul Michael Glaser), Судија Дред/Jиdge Dredd (1995, Danny Cannon), Ембер/City of Ember (2008, Gil Kenan), Тотални опозив/Total Recall (2012, Len Wiseman), Свештеник/Priest (2011, Scott Stewart), Бекство из Л. A./Escape from L. A. (1996, John Carpenter), В као вендета/V for Vendetta (2006, James McTeigue), Играч/Gamer (2009, Neveldine Taylor), Елизијум/Elysium (2013, Neill Blomkamp). ${ }^{7}$

Дистопијски филмови обично имају знатан комерцијални успех, али су често и значајна културна референца на коју се аутори могу позивати у својим радовима. Они су уједно простор укрштања душтвених наука и социолошке оптике са светом уметности и маште. Један од значајних јунака који се каткада појављује како у класичним филмским дистопијама, тако и у научно-фантастичним филмовима који имају дистопијске елементе јесте киборг.

\section{Киборг на филмском платну}

Киборг (или сајборг) подразумева спој човека и машине, односно људског тела и појединих вештачких механичких делова који обично служе као замена за изгубљене или оштећене делове људског тела, или поједине телесне функције. Киборг је спој биолошког и механичког. Обично постоји извесна забуна у вези са разликовањем киборга од других сличних јунака филмске митологије. Примера ради, филмски Терминатор није киборг, он је андроид, човеколики робот. Киборг из света седме уметности обично је човек чиja је осакаћеност надомештена вештачким деловима, који нису напросто протезе већ моћна оружја која истовремено повећавају и њихове претходне „недовољне” људске моћи и способности (усавршен вид, прецизније нишањење и пуцање, бржи покрети и трчање и боље укупне когнитивне способности).

7 Нека од наведених дела имају неколико својих наставака у оквиру заједничког филмског серијала. Овде због простора наводим само први филм из сваког серијала. 
Филмски киборг је и Робокаn/RoboCop (Paul Verhoeven, 1987), рањени полицајац Алекс Марфи/Alex Murphy из дистопијског Детроита сутрашњице, који након замене делова тела вештачким механизмима постаје „чистач” овог града оптерећеног криминалом. Реч је о једном од познатих сајберпанк супер-хероја, али и филмском лику који није без бројних контроверзи. Неки у овом лику препознају типичну регановску параноју, страх од надолазеће социјалне побуне мањина и депривираних група које су маргинализоване и због социјалне неједнакости гурнуте у криминал. Овај страх није нека новина карактеристична за осамдесете године 20. века. Још од времена Првог светског рата, у Сједињеним Америчким Државама постојао је страх средње класе (од комунизма) који неки аутори подсмешљиво називају „црвена страва". Реч је о веровању горњих и средњих слојева да су приватна предузећа у опасности од масовне револуције нижих слојева. ${ }^{8}$

Константни страхови од револуција, социјалних немира и криминала производили су у медијима велики број тзв. моралних паника. Оне су се одликовале непрекидним политичким апелима и указивањем на потребу да се америчко друштво врати својим „темељним вредностима” и очисти од оних снага које су доживљаване као опасност по постојећи друштвени и морални поредак. Филмски Робокап као суперполицајац ишао је на руку тадашњим (у то време још увек спорним) идејама о потреби милитаризације регуларне полиције и њеним изједначавањем са опремљеношћу војске (борбена возила, специјалне јединице, право на ношење дугих цеви и полуаутоматског оружја). Истовремено, овај филм представља критику индустријализације у САД и замене људи у фабричким халама роботима током седамдесетих година 20. века.

Киборг полицајац се у овом филму појављује као немилосрдни, готово фашистички чистач друштва од оних које „снаге хегемоније” доживљавају као некакав социјални талог. Због тога, поједини критичари у лику Робокапа препознају афирмацију полищијске државе и послушних и роботски испрограмираних полицајаца који беспоговорно извршавају наређења естаблишмента. Овај лик полицајцакиборга који роботски прецизно елиминише криминалце појављује се и у филмским наставцима Робокап II/RoboCop II (1990, Irvin Kershner) и Робокап III/RoboCop III (1993, Fred Dekker) снимљеним током наредних година. Серијал ових

8 Kaminski, S. (1995) Žanrovi američkog filma: pristupi kritičkoj teoriji popularnog filma, Novi Sad: Prometej; Beograd: Jugoslovenska kinoteka, str. 197. 
филмова поставља и питање корумпираности великих корпорација и центара политичке моћи, као и злоупотребе савремене технологије за повећање личног утицаја, богатства и моћи од стране „белих оковратника”. Противнике полицајца Марфија чине не само класични криминалци, већ и безлична хладна и манипулативна корпорација ОСР (Omni Consumer Products) која га је створила. Политичка власт је у замишљеној дистопијској будућности Детроита приказана махом као слаба, неодлучна и потчињена великој пословној корпорацији и њеним интересима.

Истовремено, Робокап се на личном нивоу бори и са својим новим идентитетом. Он покушава да поврати људске емоције и самосвест, али и слободну вољу и аутономију у односу према државној власти и приватној корпорацији ОСР. Римејк овог филма под називом Робокаn/RoboCop (2014, Jose Padilha) проблематизује актуелну употребу летећих дронова у војне сврхе на Блиском истоку и критички разматра идеју да се они скупа са роботима користе и за унутрашње полицијске потребе одржавања реда и закона у САД.

\section{Ратови звезда}

Најпознатији киборг са целулоидне траке јесте Дарт Вејдер (Darth Vader) из Лукасових (Lucas) Ратова звезда/Star Wars. Оног тренутка када је млади џедај ратник Анакин Скајвокер (Anakin Skywalker) прешао на „тамну страну силе”, он је задобио веће личне моћи. Али његов морални пад ускоро је био праћен и физичким сакаћењем, те након тога и претварањем у човека-машину. Његова дехуманизација у моралном смислу била је праћена и дехуманизацијом у физичком смислу. Након што је постао киборг и добио ново име Дарт Вејдер, његов пад у зло је настављен све до завршетка саме саге о џедај ратницима и Империји зла. Тек у последњем делу (Ратови звезда, епизода VI: Повратак Џедаја/Star Wars Episode VI: Return of the Jedi, 1983, Richard Marquand) у Дарт Вејдеру поново побеђује Анакин Скајвокер и реафирмисана морална и људска страна његове личности и он својеручно убија злог императора Палпетина.

У случају овог филмског киборга такође посматрамо унутрашњу борбу између људске стране личности (и слободне воље) и онога што је неки јунак постао спајањем са машином. Анакин Скајвокер/Дарт Вејдер је у суштини главни јунак овог филмског серијала, јер се он једини појављује током свих шест филмова ${ }^{9}$ у којима пратимо период од

9 У овом раду најновији седми филм поменутог серијала, под називом Ратови звезда VII: Буђење силе/Star Wars Episode VII: The Force Awa- 
његовог детињства, све до краја и реафирмисања његове људскости. Овај филмски серијал има и изражене дистопијске елементе у оном сегменту када говори о томе како се нека република претвара у тиранију, али они су напросто затомњени гомилом специјалних $C G I$ ефеката и превеликом дозом непрекидних акционих сцена.

Вејдер је заинтересовао филмску публику за идеју киборга, а Холивуд је настојао да задовољи ту потребу и другим филмовима. У условима све веће роботизације и компјутеризације у деценијама крајем 20. века „човек-машина” је будио машту људи, њихова позитивна очекивања али и страхове, тако да је филмска индустрија успешно финансијски експлоатисала мит о киборгу. У свим претходно наведеним холивудским филмовима лик киборга је више коришћен као метафора за човека који се бори за своју слободну вољу, како унутар себе самог тако и са снагама социјалног притиска и програмирања од стране ауторитета. У основи ових филмских прича је борба за реуспостављање сопствене људскости и слободне воље при одлучивању.

\section{Киборг данашьице и трансхуманизам}

Киборг је у време снимања поменутих филмова углавном био метафора, лик који постоји у научној фантастици, али данас он постоји и у реалности савременог живота. Доктор медицине Милена Чукић, истраживач са Института за неурологију, говори о томе да већ данас у формалном смислу постоје киборзи. Обично је реч о људима (ратни ветерани, инвалиди) којима су поједини делови тела замењени вештачким механичким додатком (протезом). Како она наводи, само са најновијом протезом за слух коју има око 200.000 људи на свету, могли бисмо да кажемо да имамо толико киборга. ${ }^{10}$ Већина људи још увек не схвата да данас постоје киборзи међу нама, јер их они по аутоматизму наивно замишљају као егзотичне филмске киборге, „надљуде” опремљене разним оружјима. Ово показује како филмска стварност делује на перцепцију и начин размишљања публике.

На површном нивоу, холивудски филмови о киборзима могу се посматрати само као филмови са пуно акције и гомилом специјалних опчињавајућих ефеката које изводи киборг филмски јунак. Вероватно ће се један део млађе публике задржати управо на том нивоу посматрања целе приче

kens (2015, Jeffrey Jacob Abrams), неће бити предмет разматрања јер се у њему не појављује лик киборга.

10 Јовићевић, Д. (28. јуна 2012) Концепт симбиозе, Нин, стр. 56-57. 
о киборзима. Нове вештине и моћи којима киборг располаже пробудиће инфантилне фантазије о омнипотенцији код једног дела гледалаца. Суштина је пак у озбиљном питању како такве промене делују на психу главног јунака и његов осећај сопственог идентитета. Шта је он, након што је постао киборг? Такве дилеме су актуелне због савременог човечанства које је заиста дошло до тог степена избора. Могуће је да ће људи заиста одлучити да је (биолошки) човек постао превазиђен и да је наступило време „након човека” који неки називају post-human world. Овоме је блиска филозофија трансхуманизма која заговара повећање људских психо-физичких способности уз помоћ физичког спајања биолошког тела са савременом технологијом.

Назначено питање није безначајно у социолошком смислу и изазива бројне етичке дилеме. У социјалној реалности, киборзи су постајали људи којима је била неопходна медицинска помоћ због неке врсте повреде или недостатка. Савремена филозофија трансхуманизма, пак, заговара неку врсту псеудоеволуције путем савремене технологије. То подразумева претварање и биолошки здравих људи у киборге, како би се унапредиле њихове укупне способности. Послодавцима посебно примамљиво делује идеја унапређења радних способности запослених - радници киборзи ће моћи да раде дуже, боље, прецизније уз мањи утрошак времена и енергије. Како примећује Дона Харавеј појава киборга који колонизују свет рада може учинити да чак и „ноћна мора тејлоризма личи на идилу" ${ }^{11}$ Ствара се контура неке могуће тоталитарне дистопије будућности. Трансхуманистички интонирана реклама упућена запосленима у блиској будућности може гласити слично као у најтамнијим дистопијама: „Постаните киборг о трошку наше компаније”. Реч је о препознатљивој комодификацији човека. Као што су роботи својевремено заменили хиљаде радника, може се догодити да људи који су добровољно постали киборзи замене класичне раднике. У епохи киборга и трансхуманизма класични биолошки човек постаје превазиђен и „застарео”. Киборг је метафора света који се рађа и који ће укинути до сада познате концепте природности. Он означава ново доба отворености према хибридним формама и флуктуирајућим идентитетима. ${ }^{12}$

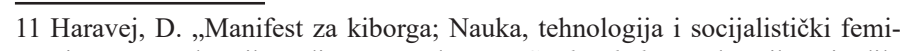
nizam osamdesetih godina XX veka“, u: Studije kulture, zbornik, priredila Đorđević, J. (2008), Beograd: Službeni glasnik, str. 605.

12 Đorđević, J. (2009) Postkultura: uvod u studije kulture, Beograd: Clio, str. 422 . 
Идеја о киборгизацији људи праћена је многим питањима. Овде није реч само о питању „унапређења способности” код здравих људи, већ и о дилеми: да ли ће такви киборзи имати слободну вољу или ће бити испрограмирани роботи којима ће послодавац или тоталитарна држава моћи да управља даљински „на дугме”. Отуда бројне оштре критике како од стране либертаријанаца и либерала, тако и левичара и конзервативаца на рачун филозофије трансхуманизма и киборга као њеног идеала „усавршеног човека” будућности. Неки претварање здравог човека у киборга виде као процес самоусавршавања и неку врсту позитивног механизованог Супермена, док има оних који у тој идеји препознају само технолошки обојену варијанту нацистичких настојања да створе натчовека. Посебно злокобно делује могућност претварања обичних војника у усавршену и испрограмирану машину за убијање (концепт supersoldier) без било каквих људских емоција и способности емпатије.

Коришћење киборгизованих „супервојника” омогућило би на бојном пољу компаративну предност малим тоталитарним режимима, али и оним ауторитарним који у етичком смислу не бирају средства како би остварили циљеве. Баш као што је својевремено и трка у нуклеарном наоружању била изнуђена чињеницом да и друге државе поседују атомско оружје, тако ће и употреба киборг војника напросто приморати све остале државе да као одговор на претњу и саме прибегну развијању таквих осавремењених војних програма. Оног тренутка када утрка у наоружању отпочне и на пољу киборгизације, све досадашње етичке дилеме падају у воду пред утилитарним разлозима.

\section{Човек у ексоскелету}

Ново време је донело и знатно измењен приказ киборга на филмском платну. Он сада није трагична личност растрзана између механичких делова и своје људске природе. Идеју полу-механичког „усавршеног човека” потпуно отворено промовише и актуелни холивудски серијал о Ајронмену (Iron Man). За разлику од монструозног Дарта Вејдера, Ајронмен (односно јунак Тони Старк/Tony Stark) је приказан као шармантни плејбој, изумитељ, мултимилионер и филантроп који је решио да усаврши себе и физички недостатак настао након рањавања у Авганистану претвори у предност спајањем са механичким деловима.

Овакав трансхуманистички „постчовек” приказан је као херој који непрекидно спасава човечанство суочено са различитим изазовима. Он је савршени ратник компјутеризованог 21. века. Ајронмен се захваљујући рекламној индустрији 
наметнуо као један од најпознатијих и најпопуларнијих јунака савремене масовне културе. Овај високобуџетни холивудски серијал укључује блокбастере: Ајронмен/Iron Man (2008, Jon Favreau); Ајронмен II/Iron Man II (2010, Jon Favreau) и Ајронмен III/Iron Man III (2013, Shane Black). Филмски киборг Ајронмен се такође појављује и у тзв. кросовер (crossover) наставцима овог серијала: Осветници/The Avengers (2012, Joss Whedon) и Осветници: Ера Алтрона/Avengers: Age of Ultron (2015, Joss Whedon). У свим филмовима Тони Старк користи механички ексоскелет који може по потреби да скида онда када није укључен у акцију. Психолошке и етичке дилеме главног јунака нису примарне у овим филмовима. Он у њима покушава да као изумитељ пре свега реши одређене „техничке потешкоће” које се јављају код употребе увек нових савршенијих модела ексоскелета Ајронмена.

Ови филмови недвосмислено поручују публици да се сви животни проблеми могу решити употребом боље технологије и нових усавршених модела. Здравље и боље властите способности је могуће напросто купити, само ако сте довољно богати. Оно што у филмској причи чине најнапреднији припадници економске елите, сасвим извесно представља модел за пројекцију и идентификацију оних делова филмске публике који иначе теже да постигну тај социјални статус. Реч је о класичним процесима пројекције и идентификације о којима је својевремено детаљно писао још Едгар Морен (Edgar Morin) у својим анализама филмске уметности. Гледалац се везује за филмског јунака, поистовећује се са личностима које су му у суштини стране и осећа да доживљава искуство које у ствари нема. ${ }^{13}$

Овакви филмови са атрактивно приказаним киборзима публици нуде инфантилни рецепт за „инстант успех” у свим областима живота. Хиљаде фанова широм света који обучени у костиме Ајронмена дочекују главног глумца ових филмова приликом биоскопских премијера у великим престоницама, јасно сведоче о високом степену идентификовања са овим филмским јунаком.

\section{Resistance is futile!}

Мит киборга такође има пуно додирних тачака и са сајберпанком који слика свет у којем владају нове технологије и медији. У таквом компјутеризованом свету људска бића се „стапају са технологијом и губе контролу над тим својим




продужецима и својим новим техно-окружењем". ${ }^{14}$ Холивудски филмови о киборзима донекле јесу својеврсна (не) намерна реклама за трансхуманизам, али они га не приказују увек у светлим тоновима тако да су истовремено и упозорење о његовим штетним последицама. У појединим америчким филмовима и телевизијским серијама јасно је истакнута данас реална опасност од технолошког тоталитаризма и претварања људи у програмиране киборге. Медијски Боргови из Звезданих cmaзa/Star Trek могу послужити као упозорење о опасности од таквог технолошког тоталитаризма.

Са њима се најпре сусрећемо у телевизијској епизоди под називом $Q$ Who (16. епизода друге сезоне серије Star Trek: The Next Generation), а након тога прича о њима се продужава и у дугометражном играном филму Звездане стазе: Први контакт/Star Trek: First Contact (1996, Jonathan Frakes). Колонија Боргова је приказана као хипертоталитарно друштво, са потпуним одсуством било какве слободне воље код његових припадника који су сви киборзи. Друштво Боргова се одликује постојањем једне Краљице, а сви остали су њени поданици којима она даљински управља путем уграђених електронских делова. Принцип организације њихове колоније подсећа на начин функционисања мрава или пчела, али поједини намерно ту препознају имплицитну (и свакако предимензионирану) критику оних друштава која су попут Северне Кореје. Сам назив Борг колектив за њихово друштво који су себи дали говори о томе да је реч о колективистичком друштву. Филмски Боргови Star Trek-a нису нека засебна ванземаљска раса, већ су створени тако што су насилно отимали и чиповали припаднике свих других раса широм свемира. Њихов циљ је потпуно потчињавање и присилна асимилација у Борг колектив свих осталих бића, а главна фраза коју користе гласи: „Resistance is futile!”

Након играног филма, прича о Борговима се продужава и у телевизијском серијалу Star Trek: Voyager, као и у каснијем серијалу Star Trek: Enterprise. У првом од ових серијала приказана је једна ипак оптимистичнија слика о њима у поређењу са филмом. Писци сценарија допуштају могућност да поједини од Боргова некако постигну самосвест и развију жељу за слободом, те да се уз помоћ људског рода избаве из Борг колектива. Пример таквих бегунаца из Борг колектива најпластичније је приказан преко лика јунакиње под називом Seven of Nine, која током трајања серијала учи да од броја постане људско биће. Речју, чак и такав апсолутно тоталитарни колектив има своје „дисиденте” који желе да

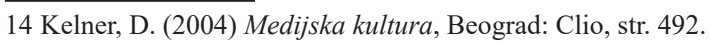


напусте једноумље. Таква порука сценариста серије обојена је једном дозом оптимизма и представља истовремено јасну поруку савременим људима који су суочени са могућношћу неког будућег технолошког тоталитаризма.

\section{Закључна разматрања}

Живот у савременом друштву чини да човек осећа непрекидну анксиозност због различитих претњи којима је свакодневно изложен. Свест о њима додатно је појачана код данашњег човека захваљујући предимензионираним и константним медијским истицањем тих претњи. Једну врсту нелагодности у култури представља и страх од потенцијалног атомског разарања човечанства, терористичких напада, еколошких катастрофа, као и од претварања савременог друштва у неку врсту глобалне тоталитарне супердржаве, попут сликовитих примера које нам нуди дистопијска литература. Дистопије се неретко у извесној мери одликују и технофобијом и страховима да би технологија могла бити злоупотребљена као средство усмерено против човека и његове слободе.

Филмске и књижевне дистопије представљају простор укрштања душтвених наука и социолошке оптике са светом уметности и маште. Дистопијски интонирани филмови постижу знатан финансијски успех на филмском тржишту, али временом постају и значајна културна референца на коју се аутори могу позивати у радовима. Оно непознато се објашњава познатим, тако да и филмски ликови киборга служе као погодна илустрација овог феномена. Они истовремено постављају многа питања у вези са процесима киборгизације човека и свим последицама које услед њих настају. Холивудска филмска остварења антиципирала су годинама уназад многе недоумице у вези са идејама трансхуманизма.

У савременој култури кључни појам постаје појам хибри$\partial a .^{15}$ Постојање разноврсних хибридних идентитета представља срж културе савременог света. Као речит пример таквог хибридног идентитета појављује се управо киборг. Он превазилази дотадашњу дихотомну поделу између човека и машине, природног и вештачког, мушког и женског. Он се одликује новим, хибридним идентитетом. Он није више само човек каквог смо познавали у претходним историјским епохама. Он је нови механизирани „постчовек” новог миленијума.

15 Đorđević, J. (2009) Postkultura: uvod u studije kulture, Beograd: Clio, str. 421. 
Киборг данас није више само холивудски маштовити поглед у будућност већ реалност садашњег тренутка. Насупрот егзотичним филмским киборзима који располажу надљудским моћима, у самој савременој социјалној реалности киборгизација се спроводи само у оним случајевима када је заиста неопходна медицинска помоћ због неког оштећена или урођеног недостатка. Истовремено, развија се идеја о томе да се киборгизацијом и здравих људи могу унапредити њихове „недовољне” људске способности. Свет рада налази се на опасној граници када ће оно што већ постоји као идејно образложена концепција о потреби унапређења радних способности запослених, прећи досадашње моралне баријере и бити представљено као нужна пословна рационалност, односно као нека врста неотејлористичке побољшане продуктивности запослених. Реч је о процесима комодификације човека зарад његовог прилагођавања потребама капиталистичког тржишта 21. века. ${ }^{16}$

Медијска индустрија користи мешавину радозналости и страха која постоји код савремених људи када се сусретну са идејама трансхуманизма. Временом се променио и тон у начину приказивања киборга у филмовима холивудске продукције. Он је некада приказиван као трагична личност растрзана између своје људске природе и силом прилика придодатих механизираних делова. Филмска публика је била на страни његове људске природе која се бори да победи наметнуте механичке додатке, али и снаге социјалног притиска. Данас холивудски киборг постаје окретни и шармантни суперхерој великог платна, а идеја киборгизације (не)свесно се рекламира као решење за све личне проблеме главног јунака. Његов једини проблем представља проналажење нових и бољих механичких решења, односно све савршенијег киборг ексоскелета.

Медијска продукција истовремено упозорава и на опасност од формирања тоталитарног уређења попут познатог Борг колектива из кога је бекство готово немогуће. Оног тренутка када киборгизација и здравих људи постане део моде или неке трансхуманистички обојене културе, увек ће над човечанством стајати сенка потенцијалног претварања друштва будућности у призоре који су нам познати из филмских и књижевних дистопија.

16 Проблем је што поред играних филмова не постоје и документарни филмови посвећени овим питањима. Један од позитивних изузетака представља филм Inhuman: The Next and Final Phase of Mankind is Here (2015, Tom Horn), који је настао као резултат истраживачког новинарства. Без обзира на извесну дозу сензационализма у приступу, овај филм на адекватан начин разматра многе од дилема у вези са трансхуманизмом. 


\section{ЂОРЂЕ ЂОРЂЕВИЋ}

\section{ЛИТЕРАТУРА:}

Bek, U. (2001) Rizično društvo: u susret novoj moderni, Beograd: „Filip Višnjić”.

Božilović, N. (2008) Umetnost, kreacija, komunikacija, Niš: Filozofski fakultet.

Đorđević, Đ. P. (2015) Film i tržište: vidovi komercijalizacije savremenog holivudskog filma, doktorska disertacija (unpublished), Filozofski fakultet, Univerzitet u Nišu, Niš.

Đorđević, J. (2009) Postkultura: uvod u studije kulture, Beograd: Clio.

Kaminski, S. (1995) Žanrovi američkog filma: pristupi kritičkoj teoriji popularnog filma, Novi Sad: Prometej; Beograd: Jugoslovenska kinoteka.

Kelner, D. (2004) Medijska kultura, Beograd: Clio.

Милосављевић, Љ. (2008) Под/стицаъе слободе: нововековна мисао о друштву, Ниш: Филозофски факултет.

Moren, E. (1979) Duh vremena I, Beograd: BIGZ.

Fukujama, F. (2002) Kraj istorije i poslednji čovek, Podgorica: CID; Banja Luka: Romanov.

Haravej, D. Manifest za kiborga; Nauka, tehnologija i socijalistički feminizam osamdesetih godina XX veka, u: Studije kulture: zbornik, priredila Đorđević, J. (2008), Beograd: Službeni glasnik, str. 604-641.

Јовићевић, Д. (28. јуна 2012) Концепт симбиозе, Нин, стр. 56-57.

\section{Филмографија:}

Ратови звезда, епизода VI: Повратак Џедаја/Star Wars Episode VI: Return of the Jedi (1983, Richard Marquand).

Тркач/The Running Man (Paul Michael Glaser, 1987).

Судија Дред/Judge Dredd (1995, Danny Cannon).

Робокап/RoboCop (1987, Paul Verhoeven).

Робокап II/RoboCop II (1990, Irvin Kershner).

Робокап III/RoboCop III (1993, Fred Dekker).

Судија Дред/Judge Dredd (1995, Danny Cannon).

Бекство из Л. A./Escape from L. A. (1996, John Carpenter).

Звездане стазе: Први контакт/Star Trek: First Contact (1996, Jonathan Frakes).

Гатака/Gattaca (1997, Andrew Niccol).

Матрикс/The Matrix (1999, Laurence/Lana Wachowski; Andrew Paul Wachowski).

Еквилибријум/Equilibrium (2002, Kurt Wimmer). 


\section{ЂОРЂЕ ЂОРЂЕВИЋ}

Сувишни извештај/Minority Report (2002, Steven Spielberg).

Ајронмен/Iron Man (2008, Jon Favreau).

Ембер/City of Ember (2008, Gil Kenan).

Израч/Gamer (2009, Neveldine Taylor).

Ајронмен II/Iron Man II (2010, Jon Favreau).

Krbuza cnaca/The Book of Eli (2010, Albert Hughes; Allen Hughes).

Свештеник/Priest (2011, Scott Stewart).

Осветници/The Avengers (2012, Joss Whedon).

Игре глади/The Hunger Games (2012, Gary Ross).

Tотални опозив/Total Recall (2012, Len Wiseman).

Ајронмен III/Iron Man III (2013, Shane Black).

Елизијум/Elysium (2013, Neill Blomkamp).

Робокаn/RoboCop (2014, Jose Padilha).

Осветници: Ера Алтрона/Avengers: Age of Ultron (2015, Joss Whedon).

Ратови звезда VII: Буђење силе/Star Wars Episode VII: The Force Awakens (2015, Jeffrey Jacob Abrams). 
ЂОРЂЕ ЂОРЂЕВИЋ

Đorđe P. Đorđević

University in Niš, Faculty of Philosophy, Niš

\title{
FILM DYSTOPIAS AND TRANSHUMANISM: THE CYBORG - FROM THE FILM MYTH TO REALITY
}

\begin{abstract}
Film art anticipated many humanistic ideas which have only recently become the actual subject of consideration. The seventh art has pointed to many ethical dilemmas and controversies that the humanity encounters when facing different challenges of transhumanism. The Hollywood films exemplify this issue most adequately in the example of the cyborg. By creating dystopian works related to cyborgs (films, TV series, graphic novels) and profiting from them, the media industry uses a mixture of curiosity and fear evident in modern people faced with an increasing development of technologies, which alters their social surroundings. Within the social reality, due to the development of technologies, the cyborg has, as a media phenomenon, over a period of time, become a part of the present and of the immediate future. We live in the times in which we question and examine the former definitions and identity of humans in the light of a new hybrid identity of the cyborg as a direct mixture of man and machine.
\end{abstract}

Key words: cyborg, dystopias, transhumanism, seventh art, film, mass media

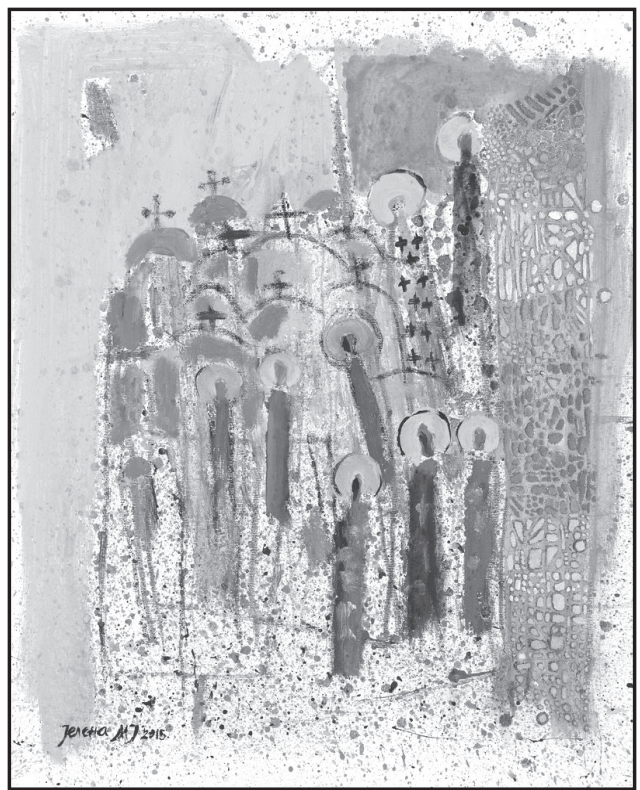

Јелена Милошевић Јовановић, Молитва, уље на платну, 60х50 цм, 2015. 